\title{
SATISFACTION WITH LIFE OF PEOPLE PARTICIPATING IN CLASSES OF THE UNIVERSITY OF THE THIRD AGE FUNCTIONING IN KUJAWSKO-POMORSKIE PROVINCE
}

\author{
SATYSFAKCJA Z ŻYCIA OSÓB UCZESTNICZĄCYCH \\ W ZAJĘCIACH UNIWERSYTETÓW TRZECIEGO WIEKU PROWADZĄCYCH \\ SWOJĄ DZIAŁALNOŚĆ W WOJEWÓDZTWIE KUJAWSKO-POMORSKIM
}

\author{
${ }^{1}$ Department and Clinic of Geriatrics of the Nicolaus Copernicus University in Torun \\ Collegium Medicum in Bydgoszcz \\ ${ }^{2}$ Department of Medical Law Basics of the Nicolaus Copernicus University in Torun \\ Collegium Medicum in Bydgoszcz
}

Su m m a r y

Introduction. The period of old age is a time of numerous changes occurring in various areas of human life, often connected with deterioration of functioning. Staying active in older age may contribute to keeping fit and independent despite limitations appearing with time.

A im. assessment of satisfaction with life at the beginning of participation in classes of the University of the Third Age and after one year of such participation and of satisfaction with life of people not taking up such an activity.

Material and methods. The respondents of the study comprised 127 people participating in classes of the University of the Third Age and 119 people who have not taken up such an activity. The level of satisfaction with life of people taking part in classes of the University of the Third Age at the beginning of their education and after a year of such education, as well as the level of satisfaction with life of people who did not take part in the classes was compared by means of the Satisfaction With Life Scale(SWLS).

Results. In the study conducted with the use of SWLS there was no statistically significant difference ( $p=0.1789$ ) between the average number of points received in both groups. After one academic year the study was reconducted among people participating in classes of the U3A with the use of SWLS. 108 respondents took part in the second study after one year of participation in classes, among whom there was a significant increase in satisfaction with life, measured by means of SWLS.

Conclusions. After a year of participation in classes of the U3A there was a significant increase in satisfaction with life of the elderly. Participation in classes of the U3A may be a factor positively contributing to welfare and well-being of elderly people.
W s tęp. Okres starości to czas wielu zmian zachodzących w różnych sferach życia człowieka, często związanych $\mathrm{z}$ pogorszeniem jego funkcjonowania. Zachowanie aktywności przez osoby starsze może przyczyniać się do zachowania sprawności i niezależności pomimo występujących wraz z wiekiem ograniczeń.
C e 1. Ocena satysfakcji z życia na początku i po roku udziału w zajęciach UTW oraz osób niepodejmujących tego typu aktywności.

Materiał i metody. W niniejszych badaniach uczestniczyło 127 osób biorących udział w zajęciach Uniwersytetu Trzeciego oraz 119 niepodejmujących tego typu aktywności. Satysfakcję z życia osób biorących udział w zajęciach UTW na początku edukacji oraz po roku udziału 
w zajęciach UTW, a także osób, które nie uczestniczyły w nich porównano przy użyciu skali SWLS.

W y n i ki. W badaniach z zastosowaniem skali SWLS nie zaobserwowano istotnej statystycznie różnicy $(p=0,1789)$ między średnią liczbą punktów uzyskaną w obu grupach. Po upływie roku akademickiego ponownie przeprowadzono badania przy użyciu skali SWLS wśród osób uczestniczących w zajęciach UTW. Do drugiego badania po roku uczest- nictwa w zajęciach przystąpiło 108 osób, wśród których zaobserwowano istotną poprawę satysfakcji z życia według skali SWLS.

Wnioski. Po rocznym udziale w zajęciach UTW zaobserwowano poprawę satysfakcji z życia osób starszych. Uczestnictwo w zajęciach UTW może być czynnikiem pozytywnie wpływającym na dobrostan i samopoczucie osób starszych.

Key words: satisfaction with life, University of the Third Age, elderly people

Slowa kluczowe: satysfakcja z życia, Uniwersytet Trzeciego Wieku, osoby starsze

\section{INTRODUCTION}

In recent years, due to an increasing number of elderly people in the general structure of population, the issues relating to problems of the period of late adulthood, thus the last stage in one's life, have been generating more and more interest. This period of life is usually connected with retirement. This is also a time of numerous, often difficult changes and situations of crisis which require re-adaptation [1]. The period of old age is often associated with passivity and withdrawal from social life, limitation of one's intellectual and physical abilities. Undoubtedly, it is also a time of changes in the area of health, social roles and cognitive functions. Such perception of this period excludes elderly people from active functioning. Yet, it should be borne in mind that it can be a time of further development, continuation of previous stages of life and of further developmental tasks [2]. Universities of the Third Age, which have become very popular in recent years, allow elderly people to continue their physical, intellectual and social activity, and they contribute to a change in perception of the period of old age itself. Activity combined with participation in classes of U3A may have significant impact on the aging process, may contribute to maintaining a good health condition and a good quality of life until late years, hence influencing the level of satisfaction with life of elderly people. Active people usually grow older without any signs of infirmity and dependence on their closest family and friends. Supporters of the theory of activity believe that successful adaptation to old age allows a person to maintain their life involvement despite appearing problems and limitations resulting from age [3]. Therefore, the period of late adulthood should not be the time of withdrawal from educational activities. It is generally believed that increased intellectual effort helps to keep one's mind efficient, which delays the process of psychological and social aging [2]. Therefore, the main task of Universities of the Third Age is to maintain intellectual activity of elderly people participating in classes. They also help the elderly to adapt to changes taking place in the society, by means of continuous development of their knowledge and skills. Participation in classes of U3A enriches both general, as well as specialist knowledge of the elderly. It requires concentration and helps to establish contacts with people of similar interests. More importantly, it fills their free time [4]. Universities of the Third Age are a form of activation, which will, with time, adapt to the expectations of new groups of elderly people. Their main assumptions and goals constitute a good direction on the way of activation of seniors, which has been confirmed by extensive research $[5,6,7,8,9,10,11]$. The aim of this study was to assess the level of satisfaction with life of people who start participation in classes of the U3A functioning in Kujawsko-Pomorskie province, as well as of people who do not take up such activity, and assessment of satisfaction with life after a year of participation in the classes.

\section{MATERIAL AND METHODS}

The study was conducted among participants of five Universities of the Third Age in KujawskoPomorskie province and among patients of the Clinic of Geriatrics of the University Hospital No. 1 of dr A. Jurasz in Bydgoszcz and patients of district clinics in Bydgoszcz, who constituted a group of reference. The age of respondents ranged between 60 and 80. 127 participants of U3A and 119 patients were qualified to the study. Satisfaction with life was assessed by means of the Satisfaction With Life Scale (SWLS) designed by E. Diener, R. A. Emmons, R. J. Larson, S. Griffin, Polish adaptation of which is prepared by Zygrfyd Juczyński. The scale consists of five questions relating 
to satisfaction with life so far, to which the respondent refers on a seven-point scale [12].

\section{RESULTS}

The average female age in the studied group was $66.7 \pm 5.0$ and there was no statistically significant difference from the average male age, which was 66.9 $\pm 4.7(\mathrm{p}=0.8748)$. In the reference group the average female age was $67.2 \pm 5.9$ and there was also no statistically significant difference from the average male age, which was $68.9 \pm 5.0 \quad(\mathrm{p}=0.1269)$. Inhabitants of cities constituted $95.3 \%$ in the studied group and $95.0 \%$ in the reference group ( $\mathrm{p}=0.9080)$. No statistically significant difference was observed between the average age of participants of the study living in the city and in the countryside, both in the studied group ( $\mathrm{p}=0.1653)$, as well as in the reference group $(\mathrm{p}=0.6732)$. In the studied group only individuals with primary or vocational education decided to take part in U3A. Distribution of people with different levels of education differed statistically significantly between the studied group and the reference group $(\mathrm{p}=0.0000)$. Among students of U3A $81.0 \%$ of men and $42.5 \%$ of women had higher education and $19.0 \%$ of men and $55.7 \%$ of women had secondary education. In both groups there was the biggest representation of people in relationships. Yet, in the reference group they constituted $61.3 \%$ and in the studied group $45.6 \%$. Distribution of the number of people with regard to the number of points received by means of SWLS in the studied group before the start of classes at $\mathrm{U} 3 \mathrm{~A}$ and in the reference group is presented in Figure 1.

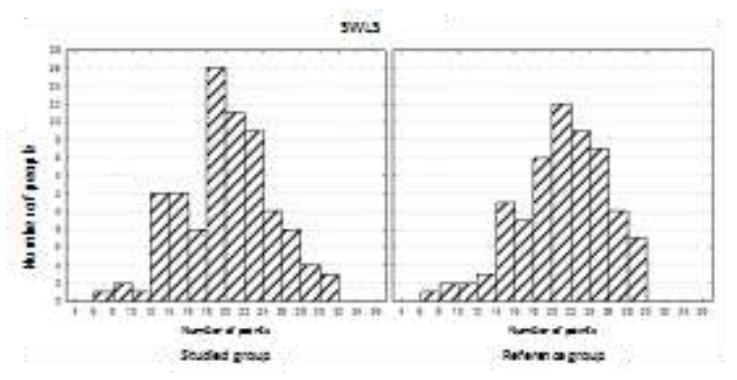

Fig. 1. Distribution of the number of people with regard to the number of points on SWLS

Ryc. 1. Rozkład liczby osób względem liczby punktów w skali SWLS

The average number of points received by respondents in the studied group was $20.64 \pm 4.91$ and there was no statistically significant difference from the average number of points received by respondents in the reference group, where it was $21.47 \pm 4.77$. The number of points received on SWLS does not depend on age. In the second stage of study after the end of an academic year, there were 108 students of U3A participating. In the study conducted after the end of an academic year the re-assessment of satisfaction with life in the studied group at the end of the academic year indicated that the average number of points received by means of SWLS was $22.05 \pm 4.35$ and it was statistically significantly higher than the number of points received before the beginning of classes, which was then $20.88 \pm 4.48$ ( $\mathrm{p}=0.0000)$. The change in the number of points received by means of SWLS does not depend on age. Sex, marital status, education and place of living do not have statistically significant impact on the average increase in points on SWLS. The result of SWLS did not change in the case of 19 respondents, there was a decrease in the case of 21 respondents and in the case of 68 respondents there was an increase in the number of points received after one academic year. The biggest decrease of 6 points was identified in the case of 2 respondents and the biggest increase of 7 points was identified in the case of 4 respondents.

\section{DISCUSSION}

Prolongation of human life connected with fast development of medicine makes a human face new challenges and realize new problems, not only related to the health of elderly people, but also to their presence in social life. In the near future, the population of elderly people is going to grow significantly, hence it now requires taking up immediate measures aimed at activation of this group, not only for the benefit of this group itself, but for the whole society $[13,14,15,16]$. In recent years, due to increase in the population of elderly people in the general structure of population, the issues relating to the quality of life have been generating more and more interest. The literature suggests that among activities preventing social exclusion, Universities of the Third Age are particularly noteworthy $[17,18,19,20]$. What was taken into consideration in this study, was the level of satisfaction with life of participants of U3A at the beginning of their education and after a year of participation in classes of U3A. At the same time, a group of people not taking up such activity was studied. The reference group comprised 119 people of 
both sexes, who met the criteria of choice. Both the studied group and the reference group were similar in terms of their age and place of living. In general, 246 people were qualified to the study, including 187 women $(76.0 \%)$ and 59 men $(24.0 \%)$. A bigger percentage of women taking part in the study was observed in the studied group, as well as in the reference group. The studied group consisted of 106 $(83.5 \%)$ women and $21(16.5 \%)$ men, and the reference group consisted of 81 (68.1\%) women and 38 (31.9\%) men. A bigger percentage of women in the studies involving elderly people has also been observed in publications of other authors [21, 22, 23]. Among the participants of the study, the number of inhabitants of cities constituted $95.3 \%$ in the studied group and $95.0 \%$ in the reference group. It also should be noted that there was no statistically significant difference between the average age of participants of the study living in the city and in the countryside, both in the studied group $(\mathrm{p}=0.1653)$, and in the reference group $(\mathrm{p}=0.6732)$. The study conducted among participants of U3A allows to conclude that people taking part in classes of U3A were better educated than people not taking up such activity. Students of U3A had secondary and higher education. Therefore, the study suggests that the studied group of people participating in classes of U3A differed with statistical significance from the reference group in terms of education $(p=0.0000)$. Students of U3A had a higher level of education. The Satisfaction With Life Scale (SWLS) was used in order to measure the level of satisfaction with life of students of U3A at the beginning of their education and after a year of participation in classes and the level of satisfaction with life of people not taking up such activity. The results received in this study among people from the studied group at the beginning of their education and of the reference group indicated no statistically significant difference $(p=0.1789)$. Both groups assessed the level of their satisfaction with life similarly. Another study in this field was re-conducted among people participating in classes of U3A at the end of an academic year. 108 people took part in this study. It turned out that the level of satisfaction with life after a year of classes at U3A, measured by means of SWLS, increased statistically significantly $(\mathrm{p}=0,0000)$, compared with the result received at the beginning of education. It also needs to be added that the level of satisfaction with life both before, as well as after a year of education did not depend on age. Similar observations were made by
Marcinek [24] in his publication. His study suggests that age does not influence satisfaction with life. He believes that aging as such does not correlate with the level of satisfaction with life and the quality of life is connected with more than the age of respondents itself. What is more, in this study sex, marital status, education and place of living have no statistically significant influence on an average increase in the number of points in SWLS scale. Furthermore, Marcinek did not observe any significant differences in the level of satisfaction with life between a group of pensioners participating in classes of U3A being in marital relationships and a group of single people, which remains in accordance with current studies. Nevertheless, Marcinek indicated that there is a difference in the level of satisfaction with life between people with different education, which is not in accordance with the results received in this study [24]. However, the results of studies of various authors in the field of a relation between the level of education and the increase in the number of point on SWLS are not clear $[25,26]$.

\section{CONCLUSIONS}

After a year of participation in classes of U3A an increase in the level of satisfaction with life of elderly people was observed. This may suggest that participation in classes of the University of the Third Age could be a factor positively influencing the wellbeing of elderly people and, more importantly, this type of activation of elderly people may be related to positive aging. An appropriate lifestyle and continuous process of gaining knowledge by participants of U3A may have positive influence on their well-being.

\section{REFERENCES}

1. Polak A., Izdebski P.: Bilans życia i poczucie koherencji osób starszych w zależności od ich aktualnej sytuacji życiowej. Gerontol Pol 2005; 13: 188-194.

2. Zielińska-Więczkowska H., Kędziora-Kornatowska K. Starość jako wyzwanie. Gerontol Pol 2008; 16: 131-136.

3. Straś-Romanowska M.: Późna dorosłość. Wiek starzenia się. W: Harwas-Napierała B., Trępała J. (red.): Psychologia rozwoju człowieka. Rozwój funkcji psychologicznych. Wyd. PWN, Warszawa 2006: 268270.

4. Hrapkiewicz H.: Uniwersytety Trzeciego Wieku jako jedna $\mathrm{z}$ form kształcenia osób starszych. Chowanna 2009; 33: 115-127.

5. Fabiś A.: Edukacja seniorów - odpowiedź na wymagania współczesności. Edukacja Dorosłych 2006; 1/2: 33-44 
6. Halicki J.: Edukacja w starości jako działanie poprawiające jakość życia seniorów. Chowanna 2009; 33: 203-212.

7. Konieczna R.: Znaczenie Uniwersytetów Trzeciego Wieku w życiu ludzi starszych. Edukacja Dorosłych 1997; 4: 58-66.

8. Kozieł D., Trafiałek E.: Kształcenie na Uniwersytetach Trzeciego Wieku a jakość życia seniorów. Gerontol Pol 2007; 15: 104-108.

9. Kuchcińka M.: Edukacja przeciw marginalizacji seniorów. Chowanna 2009; 33: 173-186.

10. Orlińska K.: Czynniki motywacji edukacyjnej dorosłych. Edukacja Dorosłych 2002; 2/3: 37-43.

11. Trafiałek E.: Uniwersytety trzeciego wieku wobec ekskluzji społecznej ludzi starych - stan i perspektywy w ujęciu porównawczym. Edukacja Dorosłych 2003; 3: 2430.

12. Juczyński Z., Narzędzia pomiaru w promocji i psychologii zdrowia. Pracownia Testów Psychologicznych, Warszawa 2009: 134-139.

13. Borowicz A.: Aktywność fizyczna jako niezbędny element pozytywnego starzenia się. W: WieczorkowskaTobis K., Talarska D. (red.): Pozytywna starość. Poznań 2010: 175-183.

14. Gębska-Kuczerowska A.: Ocena zależności między aktywnością a stanem zdrowia ludzi w podeszłym wieku. PrzeglEpidemiol 2002; 56: 471-477.

15. Kaczmarczyk M., Trafiałek E.: Aktywizacja osób w starszym wieku jako szansa na pomyślne starzenie. Gerontol Pol 2007; 15: 116-118.

16. Kałka D., Sobieszczańska M., Marciniak W: Aktywność fizyczna jako element prewencji chorób sercowonaczyniowych u osób w wieku podeszłym. Pol MerkLek 2007; 22: 48-53.

17. Boczukowa B.: Edukacja trzeciego wieku jako czynnik kształcenia i wychowania dorosłych. Edukacja Dorosłych 2004; 3: 57-61.

18. Orzechowska G.: Uniwersytet III Wieku miejscem kontynuacji i wyzwalania działań na rzecz środowiska społecznego. Edukacja Dorosłych 2003; 2: 49-55.

19. Senkowska I.: Uniwersytet Trzeciego Wieku szansą na lepszą starość - spojrzenie młodego człowieka . Edukacja Dorosłych 2002; 2/3: 93-97.

20. Szarota Z.: Przestrzeń edukacyjna Uniwersytetu Trzeciego Wieku. E-mentor 2008; 25: 71-76.

21. Muszalik M., Kędziora-Kornatowska K.: Jakość życia przewlekle chorych pacjentów w starszym wieku. Gerontol Pol 2006; 14: 185-189.
22. Płaszewska-Żywko L., Brzuzan P., Malinowska-Lipień I., Gabryś T.: Sprawność funkcjonalna u osób w wieku podeszłym w domach pomocy społecznej. ProblHigEpidemiol 2008, 89: 62-66.

23. Ziębińska B., Uniwersytety Trzeciego Wieku jako instytucje przeciwdziałające marginalizacji osób starszych. http:/www.sbc.org.pl/Content/7028/doktorat2757.pdf.

24. Marcinek P.: Funkcjonowanie intelektualne i subiektywna jakość życia u osób wieku emerytalnym. Gerontol Pol 2007; 15: 76-81.

25. Jachimowicz V., Kostka T.: Satysfakcja z życia starszych kobiet. GinekologPrakt 2009; 17: 27-32.

26. Requena C., López V., Ortiz T.: Satisfaction with life related to functionality in active elderly people. ActasEspPsiquiatr 2009; 37: 61-67.

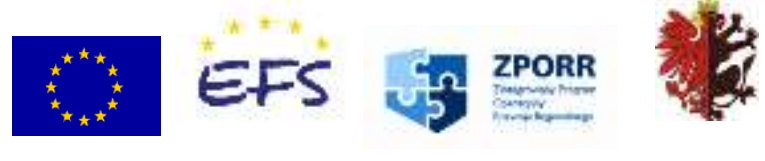

Projekt jest współfinansowany przez Unię Europejską z Europejskiego Funduszu Społecznego oraz Budżetu Państwa w ramach Zintegrowanego Programu Operacyjnego Rozwoju Regionalnego

Address for correspondence:

dr Anna Grzanka-Tykwińska

Department and Clinic of Geriatrics

of the Nicolaus Copernicus University in Torun

Collegium Medicum in Bydgoszcz

85-094 Bydgoszcz

M. Curie-Skłodowskiej 9 Street

Tel/fax (052)-585-49-00

e-mail: grzankaanna@wp.pl

Received: 3.10.2014

Accepted for publication: 17.11.2014 